\title{
PRODUÇÃO DA NATUREZA E IMPASSES SOCIOECOLÓGICOS NO EXTREMO SUL BAIANO: CONSIDERAÇÕES SOBRE MUDANÇAS CLIMÁTICAS GLOBAIS E A INDÚSTRIA DE PAPEL E CELULOSE
}

\author{
LA PRODUCCIÓN DE LA NATURALEZA Y DILEMAS SOCIO- \\ ECOLÓGICOS EN EL EXTREMO SUR DE BAHIA: CONSIDERACIONES \\ SOBRE EL CAMBIO CLIMÁTICO Y LA INDUSTRIA PAPELERA \\ PRODUCTION OF NATURE AND SOCIO-ECOLOGICAL DILEMMAS IN \\ EXTREME SOUTH OF BAHIA: CONSIDERATIONS ON GLOBAL \\ CLIMATE CHANGE AND THE PULP AND PAPER INDUSTRY
}

Andrei Cornetta ${ }^{1}$

\begin{abstract}
RESUMO: Diante do posicionamento do Brasil nos debates internacionais sobre mudanças globais do clima, bem como as políticas que o governo vem adotando internamente, este artigo analisa as maneiras pelas quais estas se desdobram territorialmente. Mais especificamente, busca-se analisar criticamente as relações entre políticas nacionais sobre mudanças climáticas e a agroindústria, em especial o setor de papel e celulose e suas implicações para o campo brasileiro. Como estratégia para particularizar estas relações, toma-se como estudo de caso as iniciativas da empresa Suzano Papel e Celulose S.A. no extremo sul da Bahia e suas atividades relacionadas ao mercado internacional de compensação de gases efeito estufa.
\end{abstract}

PALAVRAS-CHAVE: mudanças climáticas; indústria de papel e celulose; monocultura; produção da natureza

RESUMEN: Dada la posición de Brasil en los debates internacionales acerca del cambio climático global y las políticas que el gobierno ha adoptado internamente, este artículo analiza las formas en que estas se desarrollan territorialmente. Más específicamente, se trata de analizar críticamente la relación entre las políticas nacionales sobre el cambio climático y la agroindustria, en especial el sector papelero, y sus implicaciones para el campo brasileño. Como estrategia para particularizar estas relaciones, se toma como estudio de caso las iniciativas de la empresa Suzano Papel e Celulose SA en el extremo sur de Bahia y sus actividades relacionadas con el mercado internacional de gases invernadero.

PALABRAS CLAVE: cambio climático; industria papelera; monocultivos; producción de la naturaleza

ABSTRACT: Given the positioning of Brazil in international discussions about climate change and the policies that the government has adopted internally, this paper analyzes the ways in which these policies unfold territorially. From a critical perspective, this research analyzes the relationship between national policies on climate change and agribusiness, especially the pulp and paper

${ }^{1}$ Doutorando pelo programa de Pós-Graduação em Geografia Humana da Universidade de São Paulo (FFLCH/USP). E-mail: andreicornetta@usp.br 
sector and its implications for the Brazilian countryside. As a strategy to particularize these relationships, it is taken as case study the initiatives of Suzano Group in the extreme south of Bahia and its activities related to the international market to offset greenhouse gases.

KEYWORDS: climate change; pulp and paper industry; monoculture; production of nature

\section{INTRODUÇÃO}

Uma paisagem geometrizada por disposições de eucaliptos perfilados é o que marca o trajeto entre os estados do Espírito Santo e Bahia. Com exceções dessa geometrização (manchas urbanas, corpos d'água, produção agropecuária, reservas legais, etc.), o que se vê é o predomínio de uma mesma espécie vegetal organizada na paisagem e suas decorrências no território; seja no fluxo de madeiras sendo transportadas pelas rodovias ${ }^{2}$, no comprometimento dos recursos hídricos ${ }^{3}$, na monotonia da paisagem e da produção de gêneros agrícolas ${ }^{4}$, ou em cidades fragilizadas e extremamente dependentes do setor de papel e celulose ${ }^{5}$.

\footnotetext{
2 As rodovias que cortam a cidade Mucuri (BR-101 e BA-698) sofreram um aumento exponencial nas últimas décadas no volume de tráfego de caminhões de grande porte que transportam madeira e celulose em direção ao Espírito Santo. Esse intenso fluxo, além de acelerar a deterioração das rodovias tem levado a um crescimento no número de acidentes.

3 "Hoje nossos córregos estão indo embora. E o que é? [...] Estamos cercados por eucalipto. Aqui dentro dessas plantações de eucaliptos têm várias lagoas, açudes e hoje está tudo seco. As cisternas do assentamento estão todas secando e ninguém tem água" (depoimento de um dos coordenadores do assentamento Zumbi dos Palmares do Movimento dos Trabalhodres Rurais Sem Terra (MST), Mucuri, Bahia).

4 "Acho errado eles só plantarem eucalipto, acho errado eles não darem prioridade para outras coisas. Chega a comprometer a produção de alimentos sim. Tem muito eucalipto aqui no extremo sul da Bahia. Vindo de lá para cá você vai ver alguns assentamentos no meio dos eucaliptos. A gente tenta mudar um pouco isso [...]. Acho que eles deveriam rever isso e incentivar a produzir mais alimentos para as famílias da redondeza" (depoimento de um dos coordenadores do assentamento Zumbi dos Palmares do MST, Mucuri, Bahia).

5 Conforme a Avaliação Ambiental Estratégica dos Planos de Expansão da Silvicultura de Eucalipto e Biocombustíveis no Extremo Sul da Bahia, "a fase industrial da cadeia de celulose é geradora de empregos nos centros urbanos, perdendo para o Turismo em termos de capacidade de geração de empregos formais. Como consequência, verificou-se o aumento da população urbana, implicando na busca de empregos e novas oportunidades nas cidades, ocasionando um crescimento desordenado das áreas urbanas e a criação de novas paisagens locais". Por outro lado, este mesmo estudo mostra que "a indústria de celulose no Extremo Sul é considerada como poupadora de mão-de-obra, pouco contribuindo no sentido de absorver grandes contingentes de trabalhadores. $O$ conjunto de dados relativos à ocupação e à renda
} 
Produção da Natureza e Impasses Socioecológicos no Extremo Sul Baiano: Considerações Sobre Mudanças Climáticas Globais e a Indústria de Papel e Celulose, pp. 141-171.

Na aparência, não há nada de incomum em quilômetros de eucaliptos plantados em linha. As diferenças, vistas apenas nos laboratórios, podem estar nas células de árvores produzidas a partir da inserção de um gene de outra espécie - a Arabidopsis thaliana6. "Com a alteração, elas se tornam capazes de produzir $20 \%$ mais madeira em relação aos congêneres Eucalyptus"7. Trata-se de um experimento desenvolvido pela Futura Gene, empresa de biotecnologia de origem israelense, e adquirida pelo Grupo Suzano S.A. em julho de 2010.

De acordo com a pesquisa realizada pela empresa, o gene introduzido no eucalipto codifica uma das enzimas específicas que participam da formação química da celulose, a endoglucanase. Segundo Eugenio Ulian, vice-presidente de assuntos regulatórios da Futura Gene:

Descobrimos uma forma de, por meio da expressão do gene da Arabidopsis thaliana para essa enzima nas plantas, alterar a estrutura da parede celular (que é composta de celulose) das árvores transgênicas. Dessa forma, o gene exógeno faz com que as células depositem mais celulose na formação das paredes celulares da árvore, o que, no caso de espécies como o eucalipto, resulta num maior volume de madeira ${ }^{8}$.

Nos anos 1970, quando foram feitas as primeiras experiências com DNA recombinante em plantas ${ }^{9}$, novas perspectivas de exploração agrícola se abriram. A engenharia genética passou a oferecer instrumentos (sobretudo à agricultura capitalista) para a introdução de um capital fixo específico em espécies vegetais.

não refuta a hipótese do baixo impacto social dos complexos florestal-celulose em termos de geração de ocupação e distribuição de renda" (SEMA; LIMA, 2011, p. 34).

${ }^{6}$ Trata-se de uma herbácea da família das Brassicaceae e é um dos organismos modelo para o estudo de genética em botânica. Foi a primeira planta cujo genoma foi completamente sequenciado. Para maiores informações sobre esta espécie acessar <http://www.arabidopsis.org>. Acesso em: 23 jun. 2013.

7 Revista da FAPESP, fev. 2013. Disponível em: <http://revistapesquisa.fapesp.br/2013/02/11/mais-celulose-por-centimetro-quadrado>.

Acesso em: 20 jun. 2013.

${ }^{8}$ Ibidem.

9 Trata-se de uma técnica que possibilita o corte e a ligação de fragmentos de DNA (genes) podendo ser removidas de um organismo, ligadas a sequências regulatórias e inseridas em outros organismos. Para maiores informações sobre o tema, ver: EMBRAPA. "Transformações de plantas". Documentos/Embrapa Cerrado, Brasília, n. 102, 2003. 
A transgenia é uma das maneiras pelas quais o conhecimento científico é introduzido na agricultura, não apenas enquanto capital fixo materializado em tecnologias ou máquinas, mas na produção de novas espécies vegetais ou sementes dotadas de maior capacidade produtiva.

Importante destacar a particularidade quanto a esse capital fixo acoplado à planta que, ao lado de todos os "melhoramentos da natureza" aumento de biomassa, taxa de crescimento, imunidade a organismos xilófagos, etc. -, produz-se uma nova espécie vegetal, uma outra "natureza".

O papel da ciência, como discute Castree (2001, p. 194), é fundamental contemporaneamente nas relações entre sociedade e natureza, ao mesmo tempo que sua "natureza" é incompreendida. "Sem pesquisas científicas e as novas tecnologias que dela decorrem, os seres humanos não teriam capacidade de refazer a natureza da maneira que se faz atualmente". Demeritt (2001) compactua com essa ideia e reforça ainda que a ciência tem um papel fundamental na (re)transformação da natureza materialmente, mas, também, conceitualmente.

Antes mesmo da grande expansão da agricultura geneticamente modificada pelo mundo, ou do primeiro animal clonado em um laboratório, em 1984, o geógrafo Neil Smith, cunhou a expressão "produção da natureza" em seu livro Desenvolvimento desigual. O que era e continua sendo tão apreensivo e intuitivo sobre o argumento de Smith foi a afirmação de que no século XX a humanidade não apenas "interage com", "interfere na", ou mesmo "altera" a natureza, mas a produz materialmente (Ibidem, 2001, p. 191). Como o próprio Smith coloca,

\footnotetext{
A produção da natureza não somente oferece um fundamento filosófico para se discutir o desenvolvimento desigual do capitalismo, mas é um resultado muito real do desenvolvimento desse modo de produção. O que mais nos choca com essa ideia da produção da natureza é que ela desafia a separação convencional e sacrossanta da natureza e da sociedade, e o faz com indiferença e sem pejo. Nós estamos acostumados a conceber a natureza como exterior à sociedade, primitiva e pré-humana, ou ainda como um grande universo no qual os seres humanos não são senão pequenas e simples peças. [...] É o capitalismo que ardentemente desafia a separação que nos foi legada da natureza e da sociedade e mais com orgulho do que constrangimento (SMITH, 1988, p. 20).
} 
Produção da Natureza e Impasses Socioecológicos no Extremo Sul Baiano: Considerações Sobre Mudanças Climáticas Globais e a Indústria de Papel e Celulose, pp. 141-171.

Neste sentido, como o autor indica, a ideia de produção da natureza pode oferecer instrumentos analíticos ao exame do desenvolvimento geográfico desigual do capitalismo, assim como seus reflexos nas transformações agrárias atuais e, particularmente neste artigo, nas transformações impulsionadas pela expansão do eucalipto no extremo sul da Bahia.

No argumento de Smith as especificidades da produção da natureza sob o capitalismo passam, necessariamente, pelas determinações que a lógica do valor de troca acarreta às relações entre sociedade e natureza: "A produção capitalista (e a apropriação da natureza) é acompanhada não pela satisfação das necessidades em geral, mas pela satisfação de uma necessidade particular - o lucro" (Ibidem, 1988, p. 94).

A racionalidade econômica, que conduziu durante dois séculos um sistema de produção marcado por excessos e desperdícios, ajusta-se, mais recentemente, a um modelo que passa a incorporar parte de suas externalidades ambientais ${ }^{10}$ em seu processo produtivo.

Essa tendência configura-se diante do discurso alarmista que se cria em torno das questões ambientais, sobretudo em relação às mudanças globais do clima e das consequências que este fenômeno causa no mundo inteiro. Esse discurso vem impulsionando mobilizações políticas que, por sua vez, criam novas formas de investimentos em recursos até então "nãomercadorizados", como a variedade de serviços ambientais ${ }^{11}$ e os próprios créditos de carbono, que surgem como um ativo financeiro, uma nova

\footnotetext{
${ }^{10}$ A origem do conceito de "externalidade" na teoria econômica decorre do pensamento do economista inglês Arthur C. Pigou que, nos anos 1920, discutiu as maneiras compensatórias de equilibrar os problemas gerados pelas externalidades negativas. Pigou (1946) foi um dos primeiros a estabelecer o conceito de externalidades, o que mais tarde viria a ser aplicado em relação às externalidades ambientais com a lógica do "poluidor pagador".

${ }^{11}$ Existem diversas definições do que sejam os serviços ou bens ambientais. Documentos da Organização para a Cooperação e o Desenvolvimento Econômico (OCDE) tem tratado do assunto e abordando tais atividades como aquelas que tem por finalidade auferir, prevenir, mitigar ou corrigir danos ambientais causados à água, ao solo, ao ar, incluindo os problemas relacionados ao desperdício, poluição e danos aos ecossistemas. Para maiores detalhes ver: OCDE. Environmental goods and services. An assessement of the environmental, economic and development benefits of further global and trade liberalisation. Paris: OECD/OCDE, 2000.
} 
mercadoria dotada de características próprias referentes ao seu valor-de-uso - "compensar emissões de gases efeito estufa".

O que se busca em parte como "externo" é, na verdade, gerado internamente ao sistema produtivo. A condução é pela dialética "interiorexterior" (LUXEMBURGO, 1984; HARVEY, 2004), a qual se apresenta como um movimento contraditório nas entranhas da dinâmica capitalista. A violação da integridade da natureza por meio da degradação ou, inclusive, da destruição das condições naturais de produção e reprodução, não é algo externo à economia, mas pertence a seu desenvolvimento contraditório. Entretanto, em certa racionalidade econômico-ecológica as sobras da transformação da matéria e da energia, esses "não-valores", denominados de "externalidades ambientais", convertem-se em capitais latentes.

Notadamente, essas atividades estão relacionadas com políticas sobre mudanças climáticas, especialmente com as ocorridas no âmbito das chamadas "políticas mitigadoras" e com os mercados internacionais de compensação de gases efeito estufa. Dentre as várias modalidades de atividades consideradas como "mitigadoras" de emissões de gases efeito estufa ${ }^{12}$, inclui-se o chamado "sequestro florestal de carbono".

Resumidamente, esta atividade possui a função de produzir biomassa e consequentemente estocar, ou fixar, carbono nas folhas, caules, raízes e principalmente no tecido lenhoso das árvores ${ }^{13}$. Após a quantificação do carbono estocado e o cumprimento de uma série de exigências técnicas ${ }^{14}$, os

\footnotetext{
12 Aqui nos referimos aos chamados "Mecanismos de Desenvolvimento Limpo" (MDL) atividades vinculadas com as diretrizes instituídas no âmbito da Convenção-Quadro sobre Mudanças Climáticas - que pressupõe uma forma subsidiária à inovação tecnológica de cumprimento de metas de redução de gases efeito estufa. Incentivos para a implantação de projetos de MDL em parques industriais, usinas sucroalcooleiras, agricultura intensiva, tratamento de resíduos, redução de emissões em usinas termoelétricas, dentre outras atividades, surgem das mais diversas linhas de créditos e fundos de investimentos. Para uma leitura mais completa ver: CORNETTA, A. A financeirização do clima: uma abordagem geográfica do mercado de carbono e suas escalas de operação. São Paulo: Annablume, 2012. 13 "Cada árvore de eucalipto pode sequestrar até $20 \mathrm{~kg}$ de gás carbônico por ano. Um hectare de floresta jovem sequestra, em média, 35 toneladas de $\mathrm{CO}_{2}$ por ano. Por outro lado, o consumo de água do eucalipto varia de 800 a 1,2 mil litros por metro quadrado. Isso significa que para produzir um quilo de madeira da planta são necessários 350 litros de água" (ROCHADELLI, 2001).

${ }^{14}$ O baseline, definido no Art. 44 do Protocolo de Quioto, é o parâmetro quantitativo para a valoração dos créditos de carbono. Disponível em: <http://cdm.unfccc.int/EB/index.html>. Acesso em: 15 dez. 2008.
} 
Produção da Natureza e Impasses Socioecológicos no Extremo Sul Baiano: Considerações Sobre Mudanças Climáticas Globais e a Indústria de Papel e Celulose, pp. 141-171.

participantes podem pleitear créditos compensatórios de carbono e negociálos nos mercados ad-hoc ${ }^{15}$.

Atualmente, em Mucuri, município localizado no extremo sul da Bahia, a Suzano desenvolve o projeto "Pegada de Carbono", cuja finalidade é contabilizar as emissões totais da empresa, desde o plantio do eucalipto passando pelo processamento industrial do papel até o destino e descarte final do produto. De acordo com Luiz Cornacchioni, diretor de Relações Institucionais da Suzano, uma "forma de buscar sinergia em um mercado atento às mudanças climáticas é realizar o Carbon Footprint, que já é um diferencial em si". Para o executivo,

A venda de créditos de carbono é como um "chantilly sobre o morango". A base mais importante, consiste em conhecer profundamente seu processo de produção (o quanto emite e absorve) e, depois, ver as oportunidades [...]. Quando existe a possibilidade de venda de créditos e de se fazer dinheiro com isso, fica ainda melhor, como com o chantilly ${ }^{16}$.

Neste sentido, problematiza-se estes novos aspectos que surgem para o setor de papel e celulose, de modo a compreender como a agricultura capitalista no Brasil vem se relacionando com os atrativos que surgem no contexto político-econômico das mudanças globais do clima.

Sendo assim, o artigo questiona os desdobramentos territoriais de tais políticas sobre mudanças do clima que vêm impactando de maneira específica o campo brasileiro: como o entendimento político/científico que se institui

\footnotetext{
15 O denominado "mercado de carbono" constitui-se com base no pagamento por serviços ambientais, que teriam por efeito compensar o excesso de emissões dos países industrializados há mais tempo e que ratificaram o Protocolo de Quioto em 1997. Há ainda os chamados "mercados voluntários" que funcionam paralelamente aos regulamentos instituídos em Quioto. No Brasil, cinco grandes empresas do setor de papel e celulose - Klabin, Aracruz Celulose, Suzano e VCP - possuem ou já possuíram projetos registrados na Chicago Climate Exchange, a primeira bolsa de valores a negociar compensações de gases efeito estufa nessa modalidade de mercado, tendo iniciado suas atividades em 2003.

${ }^{16}$ Entrevista concedida para revista especializada do setor. Ver: "Mercado de carbono ainda é celeiro de oportunidades e desafios". Revista O Papel, $1^{\circ}$ set. 2009, p. 24-27. Reportagem especial. Disponível

em: <http://www.revistaopapel.org.br/publicacoes.php?id=284\#anexo718>. Acesso em: 16 abr. 2012.
} 
internacionalmente sobre as mudanças globais do clima condicionam políticas aplicadas no Brasil? De que maneira projetos relacionados à mitigação das mudanças globais do clima são apropriados pela agricultura capitalista, sobretudo pelas monoculturas? De maneira mais detalhada, quais seus impactos no extremo sul do estado da Bahia ${ }^{17}$, região sob grande influência da monocultura de eucalipto?

Sinteticamente, questionam-se as maneiras pelas quais esses atrativos vinculados às políticas sobre mudanças do clima se convertem em novas estratégias de acumulação de capital, ao mesmo tempo em que legitimam (ambientalmente) a expansão das monoculturas de eucalipto no campo brasileiro.

Trata-se, pois, de novas formas de produção da natureza, em que a via da compensação das externalidades, somada à lógica da financeirização e ao emprego da biotecnologia, permite uma transformação intensa e profunda da natureza. O exemplo das atividades de sequestro florestal de carbono demonstra esta característica do capitalismo contemporâneo, quando a penetração do capital atinge a escala do invisível - seja na alteração genética de árvores ou valorando processos de fotossíntese, assim como a contabilidade de estoques de carbono em massas vegetais.

Estas atividades estão cada vez mais inseridas dentro das estratégias das grandes empresas do agronegócio, sobretudo no setor de papel e celulose e sucroalcooleiro ${ }^{18}$.

\footnotetext{
${ }^{17}$ O Extremo Sul da Bahia é composto por vinte e um municípios fazendo divisa ao Norte com o Sudoeste da Bahia e Litoral Sul da Bahia; ao Sul, com o estado do Espírito Santo; a Oeste, com Minas Gerais; e, a Leste, com o Oceano Atlântico. A sua posição geográfica é privilegiada, sobretudo por localizar-se no trecho da rodovia BR-101 que faz a transição entre as regiões Nordeste e Sudeste do Brasil.

18 Destaca-se o debate atual que vem discutindo a apropriação de "serviços ambientais ou ecológicos" por parte de grandes empresas, em termos de "green grabbing". Trata-se de uma denominação para designar as atuais estratégias de "mercantilização da natureza". Para mais detalhes, ver: FAIRHEAD et al. Green Grabbing: a new appropriation of nature?. Journal of Peasant Studies. 19 abr. 2012.
} 
Produção da Natureza e Impasses Socioecológicos no Extremo Sul Baiano: Considerações Sobre Mudanças Climáticas Globais e a Indústria de Papel e Celulose, pp. 141-171.

\title{
POLÍTICAS SOBRE MUDANÇAS CLIMÁTICAS E AGRICULTURA CAPITALISTA NO BRASIL
}

\begin{abstract}
Apesar dos inúmeros riscos que podem envolver monocultivos de eucalipto $^{19}$ - inclusive o comprometimento da segurança alimentar - diversos estudos e documentos relativos ao setor florestal ressaltam a importância ambiental das florestas plantadas, enfatizando sua função enquanto "sumidouro de carbono" da atmosfera. Conforme o Anuário Estatístico da Associação Brasileira de Produtores de Florestas Plantadas (ABRAF) de 2012, "do ponto de vista ambiental, as florestas plantadas têm destaque como um dos principais recursos atuais no combate às causas das mudanças do clima, devido a sua alta capacidade de fixar o carbono atmosférico" (ABRAF, 2012, p. 108).
\end{abstract}

Esta perspectiva está listada dentro das recomendações do Quarto Relatório de Avaliação do Painel Intergovernamental sobre Mudanças Climáticas (IPCC) ${ }^{20}$ como uma das "principais tecnologias e práticas de mitigação disponíveis comercialmente na atualidade".

Dentro das tecnologias e práticas de mitigação projetadas para serem comercializadas antes de 2030, o Relatório destaca, ainda, a "melhoria das espécies de árvore para aumentar a produtividade da biomassa e o sequestro de carbono, além da melhoria das tecnologias de sensoriamento remoto para

\footnotetext{
19 Conforme Viana (2004) explicita, os efeitos adversos das monoculturas de eucalipto mais acentuados estão relacionados com a grande quantidade de retirada de água do solo, "tornando o balanço hídrico deficitário, com o rebaixamento do lençol freático e até o secamento de nascentes; o empobrecimento de nutrientes no solo; a desertificação de amplas áreas, pelos efeitos alopáticos sobre outras formas de vegetação e a consequente extinção da fauna" (VIANA, 2004, p. 9). Além dos impactos verificáveis na transformação da paisagem rural (tornando-a mais geometrizada), a ocupação de extensas áreas por monoculturas vem afetando diretamente a produção de alimentos, expropriando pequenos agricultores de suas terras, bem como estimulando o êxodo rural.

${ }^{20}$ Trata-se de um Painel científico criado em 1988 pelo Programa das Nações Unidas para o Meio Ambiente (Pnuma) em conjunto com a Organização Meteorológica Mundial (OMM), com a finalidade de estudar as mudanças do clima. Os Relatórios de Avaliação do IPCC, tem sido a principal fonte de informações para os debates e tratados internacionais sobre mudanças globais do clima.
} 
análise do potencial de sequestro de carbono da vegetação/solo [...]" (IPCC, 2007, p. 17).

Em acordo com as diretrizes da Convenção-Quadro das Nações Unidas sobre Mudança do Clima ${ }^{21}$ e com os Relatórios de Avaliação do IPCC, o Plano Nacional de Mudanças Climáticas, além das referências ao sequestro florestal de carbono desempenhado pela silvicultura, ressalta o uso energético das biomassas a partir de experimentos desenvolvidos com o eucalipto: "Além dos usos energéticos mais conhecidos da biomassa, como os dos resíduos agrícolas, deve-se destacar o grande potencial existente no Brasil para o desenvolvimento de florestas energéticas, cultivadas especificamente para esse fim" (MMA; PNMC, 2008, p. 46).

Importante destacar que, dentro dos debates internacionais sobre mudanças climáticas, especialmente no âmbito da Conferência das Nações Unidas sobre Mudanças Climáticas (COP), o Brasil vem assumindo um papel de protagonista ao lado de países como China e Índia. Durante a COP-15, realizada em Copenhague em 2009, o governo brasileiro apresentou metas voluntárias de redução de gases efeito estufa (GEE) com o objetivo de reduzir suas emissões totais entre $36,1 \%$ a 38,9\% até 2020 (em relação ao ano base de $1990^{22}$ ).

Dentre as estratégias que foram traçadas para o cumprimento das metas assumidas pelo governo brasileiro, está a promoção de "ações de reflorestamento no país, expandindo a área com florestas plantadas, atualmente, destinada à produção de fibras, madeira e celulose em 3 milhões de hectares, passando de 6 milhões de hectares para 9 milhões de hectares" (MAPA; MDA, 2012, p. 14). Segundo dados das entidades regionais que representam o setor de papel e celulose,

Atualmente, o maciço de florestas plantadas no Brasil absorve um bilhão de toneladas/ano de $\mathrm{CO}_{2}$, e mais de $10 \%$ desse sequestro é absorvido pelas florestas plantadas da Bahia.

21 Para a leitura completa do texto original desta Conferência, acessar: <http://unfccc.int/files/essential_background/background_publications_htmlpdf/application/ pdf/conveng.pdf>. Acesso em: 12 ago. 2012.

${ }^{22}$ A aposta é que o país deixe de emitir entre 975 milhões e 1 bilhão de toneladas de gases efeito estufa até 2020 em relação a projeção das emissões de 1990. Ver: "Metas domésticas". Portal Brasil, 24 nov. 2010. Disponível em: <http://www.brasil.gov.br/meioambiente/2010/11/metas-domesticas>. Acesso em: 2 set. 2013. 


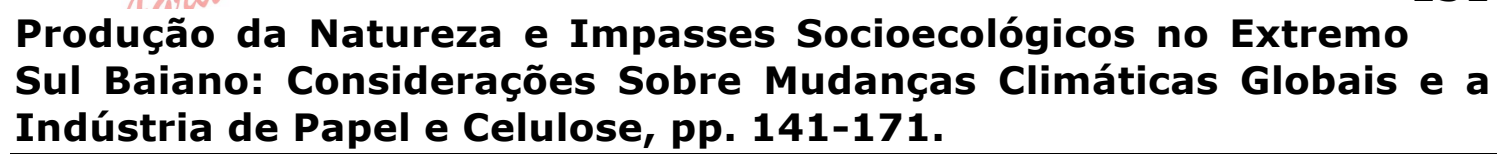

Estima-se que o sequestro de carbono pelas florestas baianas seja da ordem de 120 milhões de toneladas/ano (ABAF, 2011, p. 17).

De acordo com Alberto Mori, presidente da Associação Brasileira Técnica de Celulose e Papel (ABTCP), "o objetivo é propor projetos em conjunto entre as empresas do setor de celulose e papel para contribuir com a estabilização do clima em nível global". Valorizando o engajamento do setor, Mori segue afirmando que se trata "de uma ação pioneira, liderada pela entidade, que posicionará o setor de papel e celulose à frente dos demais setores produtivos brasileiros". A entidade alega ainda que,

As condições climáticas brasileiras, aliadas ao avanço da biotecnologia no setor, permitem a promoção de taxa de crescimento ímpar das espécies comerciais, com melhor índice de sequestro anual de carbono por hectares, se comparados aos países produtores localizados no hemisfério Norte (ABTCP, 2009, p. 5).

As relações entre as monoculturas e o mercado de compensação de gases efeito estufa vêm se estreitando gradativamente a partir dos atrativos financeiros que este novo mercado oferece ao setor; desde inovações tecnológicas mediante a incorporação de fontes energéticas alternativas, venda de créditos compensatórios de gases efeito estufa até a apropriação de uma imagem "ambientalmente responsável"23.

Neste sentido, as políticas destinadas à agricultura capitalista se direcionam à determinada agenda ambiental, especialmente ao discurso e ações voltadas a uma almejada transição para a "economia de baixo carbono"24. Catorze das principais entidades brasileiras representativas do

\footnotetext{
23 Por três anos consecutivos (2008, 2009 e 2010) a Suzano recebeu o "Prêmio Época Mudanças Climáticas", promovido pela Revista Época. No último ano, a empresa recebeu o prêmio destaque de "Melhor Inventário".

$24 \mathrm{O}$ conceito de "economia de baixo carbono" vem sendo empregado para designar um modelo econômico baseado no baixo consumo de energia, redução e gestão de emissões de gases efeito estufa. O documento "Our energy future: creating a low carbon economy", publicado em 2003, pela Secretaria de Estado para o Comércio e Indústria do Reino Unido é um dos
} 
agronegócio anunciaram, no dia 2 de setembro de 2009, a formação da "Aliança Brasileira pelo Clima", com o objetivo de contribuir com as negociações ligadas à Convenção-Quadro sobre Mudanças Climáticas ${ }^{25}$.

Em seu documento de posicionamento, a entidade destaca "a natureza global dos desafios ligados às mudanças climáticas como um dos principais motivadores da união de esforços". É apontada também "a necessidade de ações coordenadas por todas as partes envolvidas, que priorizem tecnologias economicamente viáveis e de impacto no curto prazo". O que se observa, portanto, nas práticas gerais dos setores representados por esta Aliança é a preocupação com o retorno que se pode obter com a introdução de novas tecnologias e a possibilidade de implantação de Mecanismos de Desenvolvimento Limpo ou certificados de gestão e redução de carbono.

Outro setor que vem recebendo grande destaque dentro das políticas nacionais sobre mudanças climáticas é o sucroenergético. Ressaltam-se, sobretudo, as vantagens deste setor na produção de energia renovável a partir da cana-de-açúcar e na suposta contribuição dos "biocombustíveis no combate ao aquecimento global" ${ }^{26}$.

A própria política energética do Brasil vem reforçando esta tendência com o Programa Nacional de Produção e Uso de Biodiesel, que aponta para uma perspectiva de um programa nos moldes (do discurso) da sustentabilidade, mas, ao mesmo tempo, incentivando a expansão do tradicional e oligárquico setor sucroalcooleiro ${ }^{27}$ por meio de diversos

marcos para o que se anuncia como uma "nova" economia para o século XXI. Disponível em: <http://www.gvces.com.br/index.php?r=site/conteudo\&id=157>. Acesso em: 12 jul.2013.

${ }^{25}$ Dentre algumas entidades que participam da Aliança Brasileira pelo Clima estão: Abag Associação Brasileira de Agrobusiness; ABTCP - Associação Brasileira Técnica de Celulose e Papel; Bracelpa - Associação Brasileira de Celulose e Papel; Unica - União da Indústria de Cana-de-Açúcar.

26 A estratégia de consolidação do setor sucroenergético no Brasil fica explicitada no documento "Etanol e bioeletricidade: a cana-de-açúcar no futuro da matriz energética" coordenado por Eduardo Leão de Souza, diretor executivo da Unica e pelo pesquisador do Núcleo Interdisciplinar de Planejamento Energético da Universidade Estadual de Campinas (Nipe/Unicamp) Isaias de Carvalho de Macedo. O documento apresenta oito estudos que identificam os usos energéticos da cana-de-açúcar com intuito de reforçar uma política voltada para a incorporação da cana como principal matriz energética brasileira. O terceiro estudo apresentado intitula-se "Clima: Os biocombustíveis no combate ao aquecimento global". Segundo a pesquisa, entre 2005 e 2009, o etanol brasileiro evitou a emissão de gases de efeito estufa equivalente a $60 \%$ dos créditos de carbono gerados pelos Mecanismos de Desenvolvimento Limpo no mundo (MEIRA FILHO; MACEDO, 2009, p. 21).

${ }^{27}$ De acordo com o Instituto Brasileiro de Análises Sociais e Econômicas (Ibase), a ampliação de cana-de-açúcar destinada para a produção de etanol pode prejudicar a produção de 
Produção da Natureza e Impasses Socioecológicos no Extremo Sul Baiano: Considerações Sobre Mudanças Climáticas Globais e a Indústria de Papel e Celulose, pp. 141-171.

mecanismos econômico-jurídicos; dentre os mais proeminentes, a grande oferta de créditos subsidiados pelo Banco Nacional de Desenvolvimento Econômico e Social (BNDES).

Ações consideradas "mitigatórias", isto é, que compensam ou tornam mais brando o impacto ambiental gerado, são cada vez mais adotadas por empresas que investem em Reduções Certificadas de Carbono e em práticas ambientais em geral. Ao mesmo tempo, essas empresas mantêm suas atividades que envolvem algum dano ambiental que, pela via do mercado, pode ser compensado. Aracruz, Bunge, Cargill, Fibria, Grupo Amaggi, Grupo Suzano, são apenas alguns dos nomes fortes do agronegócio que atuam no Brasil e que passam a adotar estratégias voltadas às questões "ambientais" em sua produtividade e visibilidade ante a concorrência.

Para Alexandre Comin, diretor de competitividade do Ministério da Indústria, "as iniciativas para uma economia de baixo carbono devem partir de uma política metrológica, ou seja, para uma capacidade de medição direta das emissões de gases efeito estufa". Comin ressalta ainda a importância de se adotar internamente metodologias de quantificação e gestão de carbono que estejam em conformidade com as negociações internacionais das quais o Brasil participa.

Dessa maneira, segundo o especialista, "o Brasil terá maiores condições de competitividade internacional ${ }^{28}$; a redução brasileira tem muito mais a ganhar do que perder quando a competição internacional considerar fortemente a questão das emissões" ${ }^{29}$.

alimentos no país. Além disso, o estudo aponta para outros impactos como a ameaça aos recursos hídricos, devido ao uso intensivo de agrotóxicos, riscos de saúde para os trabalhadores, dentre outros impactos. Ver: Impactos da indústria canavieira no Brasil. Em <http://www.ibase.br/userimages/Livro_BNDES.pdf>. Acesso em: 10 jan. 2013.

${ }^{28}$ O geógrafo Gilles Ardinat apresenta uma análise extremamente interessante sobre a incorporação da palavra "competitividade" nos discursos oficiais dos governos. Essa estratégia, como destaca o geógrafo, não se restringe mais apenas as empresas. Agora cidades, regiões e até mesmo as nações devem concentrar suas energias nesse objetivo: "Em sentido amplo, a competitividade designa a capacidade de enfrentar com êxito a concorrência. Aplicada aos territórios, essa noção mede o nível de inserção na geografia econômica mundial". ARDINAT, G. "Competitividade, símbolo dos paradoxos da globalização". Le Monde diplomatique Brasil, São Paulo, ano 6, edição 63, 02 out. 2012.

${ }_{29}$ Registro feito durante o "Evento Anual do Programa Brasileiro GHG Protocol" realizado no auditório do BNDES, Rio de Janeiro em 4 set. 2012. 
As características evidenciadas no avanço científico e tecnológico empregado no setor mostram que a produção da natureza, neste caso, assume um duplo aspecto quanto às estratégias de acumulação de capital: 1) criando uma nova espécie vegetal capaz de extrair um maior potencial de crescimento, assim, portanto, alterando (ou produzindo) novas características edafoclimáticas; 2) na valoração da fotossíntese visando à contabilidade de estoques de carbono em monoculturas de eucalipto.

Neste cenário, as possibilidades de flexibilização do setor de papel e celulose ganham fôlego ante a concorrência, e se portam de maneira transversal ao ciclo produtivo: partindo da elaboração de inventários de gases de efeito estufa, participação em programas voluntários de redução de emissões, desenvolvimento de projetos de compensação de emissões, adoções de metas internas de redução e ações de pesquisa e desenvolvimento na área climática.

Importante considerar que, além desse aspecto que vem se constituindo nos últimos anos como um importante fator que impulsiona o avanço (e a legitimação) das monoculturas de eucalipto no campo brasileiro, os incentivos políticos, sobretudo as estratégias de fomento, são fundamentais para a consolidação do setor no país.

\section{CONSIDERAÇÕES SOBRE POLÍTICAS DE FOMENTO E O METABOLISMO SOCIOECOLÓGICO NO EXTREMO SUL DA BAHIA}

Em Mucuri, assim como em todo o extremo sul da Bahia, as políticas de fomento foram preponderantes para a atual configuração territorial desta região e, consequentemente, para inúmeros impactos socioambientais gerados pelo setor de papel e celulose. Tais impactos alteraram fundamentalmente a estrutura fundiária da região, formada originalmente por pequenas e médias propriedades destinadas à pecuária e fruticultura. 
Produção da Natureza e Impasses Socioecológicos no Extremo Sul Baiano: Considerações Sobre Mudanças Climáticas Globais e a Indústria de Papel e Celulose, pp. 141-171.

Os fomentos configuram-se como mecanismos financeiros que incentivam proprietários de terras localizados no entorno das unidades fabris de papel e celulose (geralmente num raio de $100 \mathrm{~km}$ ) a arrendarem suas terras, ou parte delas, para o plantio de eucalipto. Esse aspecto confere uma característica particular quanto ao uso da terra pela indústria de papel e celulose e as maneiras pelas quais pequenas e médias propriedades são absorvidas pelo setor.

Os principais motivos que levam as empresas a adotarem este tipo de estratégia consistem na redução de investimentos na compra de terras, menor custo da madeira, aumento na diversificação de fontes de matériaprima, além da maior integração com proprietários rurais presentes nas proximidades das empresas (MENDES, 2005).

A Suzano vem utilizando mecanismos de financiamento como esses desde 1973, na unidade de São Paulo, e em 1992, na unidade de Mucuri, Bahia. Esta prática impulsionou a formação de florestas de eucalipto em áreas de terceiros totalizando, segundo a empresa, 58 mil hectares, sendo que 13 mil hectares plantados em 2008 (SUZANO, 2010, p. 4).

O mecanismo de financiamento que a Suzano vem utilizando na Bahia é o do tipo contratual. Trata-se de um contrato firmado entre a empresa e o produtor, no qual a empresa se compromete a investir na formação da floresta do fomentado e este assume que $95 \%$ da madeira produzida deverão ser vendidas à Suzano.

De acordo com o estudo "Mecanismos Financeiros para as Florestas Nativas no Brasil", encomendado pela Organização das Nações Unidas para Alimentação e Agricultura (FAO), esses mecanismos de fomento, na região Sul do Brasil, vêm apresentando algumas situações de risco para a sustentabilidade econômica, social e ambiental dos produtores rurais que arrendam suas terras para a plantação de eucalipto e pinus, sobretudo dos pequenos proprietários, quais sejam:

Substituição de florestas nativas, normalmente em áreas de reserva legal, por plantações de Pinus e/ou Eucalyptus, 
principalmente em pequenas propriedades; êxodo rural, devido ao interesse de "profissionais liberais" em comprar pequenas e médias propriedades para se beneficiarem do fomento para fins de geração futura de renda para aposentadoria; adoção de sistemas de manejo propícios aos objetivos industriais do fomentador e não ao objetivo de maximização da renda do produtor rural; ação governamental como agente facilitador (assistência técnica, distribuição de mudas, outras) atendendo mais aos objetivos do fomentador do que do fomentado; não valorização adequada do "custo da mão-de-obra" do produtor rural; condição "oligopsônica" das indústrias, concentrando o fomento no "entorno" de suas unidades fabris e não oferecendo alternativas de comercialização ao fomentado (MENDES, 2005, p. 41-42).

Os mecanismos de fomento, segundo o diretor da Secretaria de Meio Ambiente de Mucuri, veio surgir da necessidade das empresas expandirem suas áreas de produção.

\begin{abstract}
Existe aquela situação de pessoas que possuem áreas, mas não tem condições de plantar. Então as empresas começaram a criar um programa de fomento, onde a pessoas recebem um valor para poder plantar condicionado a vender exclusivamente para a própria empresa. Hoje nós temos no município aqueles que têm condições de plantar, as áreas das empresas, e temos aqueles que plantam pelos programas de fomento, tanto da Fibria quanto da Suzano. A maioria do nosso fomento é da Suzano ${ }^{30}$.
\end{abstract}

As alterações na estrutura fundiária, assim como as características de uso e ocupação do solo em Mucuri emergem, no primeiro momento, a partir da alta especulação dos imóveis agricultáveis em função da renda (a maior dentre todas as culturas desenvolvidas na região) atribuída ao eucalipto.

Com a chegada da silvicultura começou a especulação desses imóveis e muitas pessoas passaram a ser coagidas a vender suas terras [...]. As pessoas que venderam seus lotes foram para cidade com a expectativa de uma vida melhor para seus filhos. Hoje, essa pessoa passa fome e antes tinha a possibilidade de produzir alimento e ter o que comer dentro de sua terra ${ }^{31}$.

\footnotetext{
30 Depoimento do diretor da Secretaria de Meio Ambiente de Mucuri, Bahia.

31 Diferentes atores sociais entrevistados durante os trabalhos de campo deram depoimentos que relatavam episódios de violência e expropriação de camponeses com a chegada da
} 
Produção da Natureza e Impasses Socioecológicos no Extremo Sul Baiano: Considerações Sobre Mudanças Climáticas Globais e a Indústria de Papel e Celulose, pp. 141-171.

A partir deste momento, uma série de outras decorrências passa a afetar o metabolismo socioecológico ${ }^{32}$ desta região, colocando em risco, inclusive, a própria produção familiar de gêneros alimentícios. Os especuladores que procuram maximizar ganhos a partir do aumento da renda da terra tiveram um papel central na reformulação das relações sociais e ecológicas no extremo sul da Bahia.

A "Avaliação Ambiental Estratégica dos Planos de Expansão da Silvicultura de Eucalipto e Biocombustíveis no Extremo Sul da Bahia", estudo encomendado pela Secretaria do Meio Ambiente do Estado da Bahia $(\text { Sema })^{33}$, avalia que o processo de ocupação de atividades monoculturais vem reduzindo sensivelmente a disponibilidade de terras agricultáveis e a reprodução dos diferentes usos do solo.

As áreas com melhores condições edafoclimáticas para lavouras temporárias e permanentes vêm sendo ocupadas pela silvicultura. As áreas restantes, quando não ocupadas pela pecuária, por terem condições um pouco menos propícias, necessitam de cuidados especiais para se atingir uma boa produtividade, o que leva a uma maior pressão sobre os custos de produção e a necessidade de serviços de extensão agrícola (SEMA; LIMA, 2011, p. 37).

As transformações no uso e ocupação da terra pela monocultura de eucalipto trazem grandes mudanças na paisagem, permitindo certas regiões adentrarem nas dinâmicas econômicas nacional e internacional. Além disso, a organização territorial imposta pelas monoculturas implica em novas formas e relações de trabalho. Em Mucuri, assim como em grande parte do

monocultura de eucalipto no município de Mucuri. Neste caso, optamos por não identificar a pessoa do trecho citado.

32 Considera-se o conceito de "metabolismo" para definir os processos inerentes a relação homem-natureza. Processos pelos quais o trabalho humano, "sua própria ação, media, regula e controla seu metabolismo com a Natureza" (MARX, 1983, p. 149). Nos "Manuscritos Econômico-Filosóficos", esse aspecto é intensamente ressaltado: "A sociedade é, pois, a plena unidade essencial do homem com a natureza, a verdadeira ressurreição da natureza, o naturalismo acabado do homem e o humanismo acabado da natureza" (Idem, 1978, p. 9).

${ }^{33}$ Estudo encomendado pela Secretaria do Meio Ambiente do Estado da Bahia ao Laboratório Interdisciplinar de Meio Ambiente da Universidade Federal do Rio de Janeiro (Lima/COPPE/UFRJ) junho de 2011. Coordenação geral: Emilio Lèbre La Rovere. 
extremo sul da Bahia, essas características são relatadas da seguinte maneira:

\begin{abstract}
Inicialmente se empregou muito, mas a partir da mecanização de toda a cadeia produtiva do papel demitiu-se muito. E aquele fazendeiro que encontrava dificuldade em escoar sua produção, ou que encontrava dificuldade em produzir por conta da oscilação do preço da carne bovina acabou optando pelo fomento das empresas de papel e celulose porque ele garante uma renda programada e emprega poucas pessoas reduzindo o seu custo. O reflexo, por vezes, é a geração de bolsões de miséria em cidades pequenas ou vilas como nós temos no interior do município de Mucuri e principalmente em Caravelas, em vilas onde a população não tem possibilidade de emprego ${ }^{34}$.
\end{abstract}

Por parte dos representantes do poder público municipal a avaliação é muito parecida: "realmente, o plantio de eucalipto transformou nossa região. Gera muito emprego, mas, também, gera muitos impactos. Acabou mudando a própria cultura do povo. [...] os maquinários acabaram substituindo a mãode-obra, principalmente a mais simples" ${ }^{35}$.

O impacto da monocultura de eucalipto nesta região vem sendo objeto de intensas disputas e controvérsias que envolvem uma série de atores que vão desde os pequenos produtores rurais e movimentos sociais ${ }^{36}$, que repudiam o plantio de eucalipto, passando pelas instituições públicas em suas diferentes instâncias, os bancos e seus mecanismos de financiamento para produção de papel e celulose e mesmo as empresas especializadas na implantação dos projetos de sequestro de carbono e Mecanismos de Desenvolvimento Limpo. Outras pesquisas vêm questionando até que ponto essas práticas "desviam investimentos e ocupam terras que poderiam estar sendo utilizadas pela agricultura familiar?" (SANTOS; SILVA, 2004).

Os plantios de eucalipto, segundo o Ministério Público do Estado da Bahia, ocupam boa parte das terras agricultáveis de diversos municípios do extremo sul do estado, "como são os casos de Alcobaça, com 34,4\% de seu

\footnotetext{
34 Depoimento do diretor da Rádio 3 Corações de Itabatã, Mucuri, Bahia.

35 Depoimento do secretário de Meio Ambiente de Mucuri, Bahia.

36 Para maiores detalhes sobre a luta dos movimentos sociais contra a expansão da monocultura do eucalipto ver: "Carta de Porto Seguro". Em <http://www.fase.org.br/projetos/clientes/noar/noar/UserFiles/12/File/Rede_alerta/cartas_ manifestos/557_carta_porto_seguro.pdf>. Acesso em: 25 set. 2012.
} 
Produção da Natureza e Impasses Socioecológicos no Extremo Sul Baiano: Considerações Sobre Mudanças Climáticas Globais e a Indústria de Papel e Celulose, pp. 141-171.

território comprometido com a eucaliptocultura, Caravelas com 34\% e Mucuri com 33,5\%" (CORRÊA, 2008, p. 4). Este estudo indica que as áreas dos municípios de Nova Viçosa, Alcobaça, Caravelas e Mucuri ocupadas pela monocultura de eucalipto somam 696.800,00 hectares (Ibidem, 2008, p. 4).

Os munícipios de Mucuri e Nova Viçosa são os que mais sofrem impactos diretos de pessoas oriundas de outras regiões em busca de oportunidades. A produção agrícola caiu de tal maneira que a agricultura familiar não consegue fornecer (principalmente em Nova Viçosa) a merenda escolar ${ }^{37}$.

A alternativa a esse cenário encontra-se nos assentamentos rurais que conseguem produzir verdadeiras ilhas de alimentos em uma região tomada pela monocultura. Em Mucuri, são cinco assentamentos do Movimento dos Trabalhadores Rurais Sem Terra (MST) ${ }^{38}$ que produzem diferentes cultivos com os quais abastecem as feiras locais e a merenda escolar. De acordo com lideranças:

Só os assentamentos que produzem alimentos. Os fazendeiros que tem aqui na região só plantam eucalipto. É a melhor renda que se tem aqui. Hoje não se vê mais uma cultura de feijão, milho, uma horta... Chegou um tempo que a gente ia à feira e não tinha nada. Mas graças a Deus, como tem os assentamentos, o pessoal que trabalha com laranja, limão, aipim, horta, tomate, é que consegue fornecer alimento para a cidade. Você pode ir a qualquer uma das feiras que tem por aqui, Mucuri, Posto da Mata, Itabatã e perguntar de onde vem esse alimento. Eles vão dizer que vem dos assentamentos [...] e nós não vamos desistir, o MST aqui na Bahia tem 25 anos de luta 39 .

Há ainda o acampamento do MST "Avací Silva", localizado às margens da rodovia BA-698. Este acampamento é resultado direto das ações programadas para o Abril Vermelho de 2012, cuja fazenda Conceição da Barra, de propriedade da Suzano, foi ocupada por cerca de 150 pessoas

\footnotetext{
37 Depoimento do diretor da Rádio 3 Corações de Itabatã, Mucuri, Bahia.

38 São eles: Zumbi dos Palmares, Paulo Freire, Quilombo, Jequitiba, Cimental.

39 Depoimento do coordenador do acampamento Avací Silva (MST), Mucuri, Bahia.
} 
(BITTENCOURT, 2012). Atualmente o acampamento abriga 240 famílias em uma área de 1.800 hectares. Questionado sobre o aumento do número de famílias, um dos coordenadores do acampamento, afirma que o tamanho da área seria o suficiente para assentar todas elas.

Em relação ao comprometimento na produção de alimentos, as atividades da Suzano voltam a ser o foco das disputas no extremo sul baiano. O processo de ocupação das monoculturas de eucalipto vem reduzindo drasticamente a disponibilidade de terras agricultáveis e a reprodução dos diferentes usos do solo na região.

Muitos dos depoimentos registrados durante a visita à Mucuri enfatizam a importância dos poucos assentamentos rurais do MST para a produção de alimentos. Conforme uma das lideranças locais, "antes em qualquer lugar você via muito cultivo de alimento, mas hoje só se vê eucalipto. Tirando os assentamentos, lá fora é só eucalipto e isso é problemático".

Moradores do município também reconhecem essa importância dos assentamentos: "Eu não sou militante nem participo do dia a dia, mas percebo que há uma importância, principalmente por esses assentamentos terem revitalizado a agricultura familiar. Se hoje nós temos acesso a produtos não industrializados, produtos com menos agrotóxicos, mais limpos, é graças a eles" ${ }^{40}$, relata o comerciante.

Além dos impactos da monocultura de eucalipto em relação à segurança alimentar do extremo sul baiano, verificam-se outras decorrências específicas quanto ao rio Mucuri. Recentemente foi formada uma comissão ambiental por vereadores de Mucuri, peritos ambientais e representantes da sociedade civil, criada por iniciativa do presidente da Câmara de Mucuri, vereador Agripino Botelho Barreto, teve por objetivo apurar algumas práticas consideradas ilícitas contra o meio ambiente.

Após a visita de inspeção que fizeram à fábrica da Suzano Papel e Celulose instalada no município, foram identificadas diversas irregularidades

\footnotetext{
40 Depoimento de um morador e comerciante de Mucuri, Bahia.
} 
Produção da Natureza e Impasses Socioecológicos no Extremo Sul Baiano: Considerações Sobre Mudanças Climáticas Globais e a Indústria de Papel e Celulose, pp. 141-171.

na sua estação de tratamento e esgoto e descarga de afluentes químicos contendo metais pesados no leito do rio Mucuri.

De acordo com a imprensa local:

Denúncias de pessoas que moram próximas à ponte do rio Mucuri sob a Rodovia BR-101, a jusante das descargas da unidade industrial da Suzano, dando conta que no local eles estavam pescando peixes em estágio de agonização e aparecendo até cascudos e bagres africanos mortos apresentando verrugas avermelhadas em toda a sua pele ${ }^{\prime \prime 41}$.

Segundo Antônio Carlos Martins Filho, biólogo e membro da coordenadoria municipal de meio ambiente de Mucuri,

As verrugas avermelhadas nos peixes são de caráter dilaceradoras (sic), suspeitando que os peixes estejam sendo mortos por um material corrosivo, tipo dióxido de cloro com soda cáustica, que é justamente o produto químico usado no branqueamento do papel, procedente da celulose ${ }^{42}$.

Ainda sobre este caso, Martins Filho relata que,

Alguns pescadores que tem o hábito de pescar de baixo da ponte próximo com a divisa com o Espírito Santo, eles chegaram com uma reclamação que havia alguma substância que estava causando irritação na pele e uma queixa de dois pescadores que entraram no rio para recolher as redes e que tiveram queimaduras com uma descamação de pele [...]. Nós fomos para o rio com uma equipe de jornalismo do "Teixeira News" com a intenção de verificar a veracidade do ocorrido. Chegando lá encontramos alguns pescadores acidentados pelos supostos produtos químicos. A suspeita é que venha das descargas da Suzano ${ }^{43}$.

\footnotetext{
${ }^{41}$ Ver: "Comissão Ambiental de Mucuri x Suzano Papel e Celulose". Itabatã News. Disponível em: <http://www.itabatanews.com.br/home/leitor.php?cod=1887>. Acesso em: 27 out. 2012.

${ }^{42} \mathrm{Ver}$ "Suzano mata peixes ao poluir rios jugando dejetos contaminados". In: Reportagem Coragem, 26 mar. de 2012. Disponível em: <https://www.youtube.com/watch?v=rHIMeUqKdQ>. Acesso em: 13 set. 2012.

43 Depoimento do fiscal da Secretaria de Meio Ambiente de Mucuri, Bahia.
} 
O impacto na vida dos pescadores é patente em depoimentos dos mais experientes do rio Mucuri:

Antigamente a gente pegava cinco, seis quilos de peixe por dia. Hoje peguei no máximo três. O rio está mais poluído do que antes. Era clarinho e hoje tem uma água preta e está fraco. Também as fazendas não plantam nada na beira do rio e está tudo assoreando [...]. Tem muito pescador que está desistindo. Aqui tinha uns quinze pescadores artesanais que pescavam com a gente. Hoje só pesco eu, ele, o "Tengo" e o "Magro". Só quatro pescadores daqui de baixo que pescam com rede, que jogam uma tarrafinha ${ }^{44}$.

Outros relatos enfatizam a contaminação da água do rio e como isso vem afetando a pesca e a cultura local.

\begin{abstract}
Um dos peixes que é a predileção de todos aqui, o peruá $[. .$. até pouco tempo atrás ele era abundante. $\mathrm{E}$ por alguma razão (que a gente pode dialogar com os pescadores) esse peixe praticamente sumiu. É um peixe muito sensível a áreas contaminadas, poluídas. Hoje, os pescadores falam que tem que ir muito longe para pescar e não ter a certeza que vão voltar com algum. O que ocasionou isso? Os pescadores admitem que a poluição afugenta o peruá.
\end{abstract}

As primeiras respostas populares quanto a esses impactos negativos foram registradas na "Carta de Porto Seguro" de 2003. Diversas entidades representativas de movimentos sociais, sindicatos e comissões científicas formam a "Rede Alerta Contra o Deserto Verde", movimento que luta contra a expansão da monocultura do eucalipto para produção de celulose e carvão vegetal no Espírito Santo, Bahia, Rio de Janeiro e Minas Gerais. O tom da Carta é de denúncia "contra as profundas violações dos direitos econômicos, culturais e socioambientais provocadas por este complexo agroindustrial exportador". O documento ressalta o contrassenso entre os investimentos no setor de papel e celulose e programas governamentais como o "Fome Zero" do Governo Federal.

${ }^{44}$ Depoimento de um pescador de Mucuri, Bahia. 
Produção da Natureza e Impasses Socioecológicos no Extremo Sul Baiano: Considerações Sobre Mudanças Climáticas Globais e a Indústria de Papel e Celulose, pp. 141-171.

De um lado, volumosos investimentos continuam privilegiando uma monocultura que é destinada à produção para exportação aos países ricos, gerando pouquíssimos empregos, legitimando o latifúndio, impedindo a reforma agrária e aumentando mais ainda o êxodo rural e o desespero de milhares de famílias que ficarão sem terra e sem sustento. De outro lado, o governo apresenta um Programa Fome Zero que busca estimular a produção de alimentos, enquanto as melhores terras agricultáveis continuam sendo ocupadas por plantações de árvores ${ }^{45}$.

A Rede se pronuncia, também, contra o uso de Mecanismos de Desenvolvimento Limpo para plantações extensivas, entendendo que esses mecanismos continuam "favorecendo países do Norte que não terão que reduzir suas emissões de poluentes que contribuem para o aquecimento global, e ao aumentar as áreas de plantações, os MDLs vêm agravando o empobrecimento das populações do Sul"46.

Nesse sentido, considera-se que muitas atividades atreladas às políticas sobre mudanças climáticas globais, sobretudo as acopladas a agricultura capitalista e suas monoculturas, como em produções do setor sucroalcooleiro ou de papel e celulose, não contabilizam as externalidades ambientais que afetam negativamente as populações residentes no entorno dessas atividades.

Os efeitos considerados pelas políticas internacionais sobre mudanças do clima se restringem a uma contabilidade global de emissões de gases efeito estufa na atmosfera, enquanto as comunidades afetadas pela expansão das monoculturas no campo continuam lutando por uma sustentabilidade que as inclua.

\footnotetext{
${ }^{45}$ FASE et al. Carta de Porto Seguro. Porto Seguro, 29 de junho de 2003. Para leitura completa acessar:

<http://www.fase.org.br/projetos/clientes/noar/noar/UserFiles/12/File/Rede_alerta/cartas_ manifestos/557_carta_porto_seguro.pdf>. Acesso em: 12 mai. 2013.

${ }^{46}$ Ibidem.
} 


\section{CONSIDERAÇÕES FINAIS}

As transformações que vem impactando Mucuri, e grande parte dos municípios do extremo sul baiano, estão relacionadas não apenas com a monocultura de eucalipto, mas com processos mais profundos e intrínsecos ao desenvolvimento desigual do capitalismo contemporâneo. Tais processos dizem respeito a espoliações sistêmicas, "destruições criativas", desvalorizações, concentração de terras, monopolização do território, entre outros movimentos próprios à dinâmica do capital que recriam condições favoráveis à incorporação de ativos até então não mercantilizados (como gases de efeito estufa) ou, pelo menos, ativos que, até o momento, não obtinham forças lucrativas para o sistema.

Contraditoriamente, hoje é notória, na pauta das grandes empresas do agronegócio, a incorporação de questões ligadas ao meio ambiente e a sua degradação. Isso não elimina as preocupações legítimas com essas questões entre a população em geral. Porém, essas inquietações, entendidas como uma barreira ao modo de reprodução capitalista levou a política internacional a assumir estratégias regulatórias diante desse suposto "entrave" à economia.

Em grande parte o discurso sobre as dificuldades que a economia teria em se desenvolver em função das degradações geradas pelo sistema produtivo do capitalismo refere-se à ideia de escassez, sobretudo, das fontes fósseis de energia. Sem dúvida que é extremamente preocupante as maneiras pelas quais os recursos vêm sendo solapados e distribuídos de maneira desigual ao longo da geografia-histórica do capitalismo.

Paradoxalmente, as regras sobre como lidar com as questões ambientais são concebidas como um remédio paliativo. Os mecanismos compensatórios teriam essa função por meio tanto das inovações tecnológicas como das regras do mercado.

Nesse sentido, tais estratégias se convertem em políticas que criam condições normativas para a penetração nos territórios de capitais financeiros, estimulados pelas novidades da "economia de baixo carbono". 
Produção da Natureza e Impasses Socioecológicos no Extremo Sul Baiano: Considerações Sobre Mudanças Climáticas Globais e a Indústria de Papel e Celulose, pp. 141-171.

Inovações tecnológicas, projetos de MDL, gerenciamento de emissões de gases efeito estufa, serviços ambientais que se relacionam com as estratégias de expansão da agricultura capitalista (e suas monoculturas), são exemplos de mecanismos pelos quais o capital penetra nos territórios mais porosos e favoráveis à "mitigação das mudanças globais do clima".

Diante deste cenário, que afeta diretamente às dinâmicas do campo brasileiro, a reflexão sobre a produção da natureza (SMITH, 1988; HARVEY, 2004; CASTREE, 1995) pode contribuir para um entendimento sobre as novas estratégias de acumulação de capital (KATZ, 1998), criadas a partir da ressignificação da "natureza" 47 , inclusive das florestas plantadas.

Como visto ao longo do artigo, há um claro incentivo à expansão das monoculturas de eucalipto por parte do Plano Nacional Sobre Mudanças Climáticas, destacando essa atividade enquanto importante sumidouro de carbono da atmosfera. Além desse aspecto central, ressalta-se "o grande potencial existente no Brasil para o desenvolvimento de florestas energéticas cultivadas especificamente para esse fim".

Diversas pesquisas estão em andamento no Brasil buscando identificar as "densidades de plantio e rotações de plantações de rápido crescimento para produção de madeira para diversos fins, inclusive o energético" (PNMC, 2008, p. 46). O próprio Ministério do Meio Ambiente "tem contribuído com essas pesquisas por meio de convênio com a Rede Nacional de Biomassa (Renabio $)^{48}$, a qual tem desenvolvido projeto de cultivo de várias espécies de eucaliptos" (Ibidem).

Nesse contexto, o Estado não age apenas em função das implementações de projetos mitigatórios dos fatores que desencadeiam as mudanças do clima, mas atua, principalmente, de acordo com o discurso da modernização ecológica e correlata à almejada transição para uma economia

\footnotetext{
47 Smith nos alerta para o fato de o capitalismo construir e reconstruir paisagens como valores de troca sob o imperativo do lucro e também para o fato de que ele determina constelações particulares de produtos "naturais" em lugares particulares (SMITH, 1988).

48 Trata-se de uma rede de instituições (órgãos governamentais, universidades, instituições de pesquisa e de desenvolvimento tecnológico, empresas privadas e ONG) interessadas em pesquisa e desenvolvimento na área de energia a partir de biomassa. Disponível em: <http://www.renabio.org.br>. Acesso em : 9 jul. de 2013.
} 
de baixo carbono. Nessa perspectiva, as políticas nacionais sobre mudanças do clima enfatizam que os desafios de adaptação e mitigação podem gerar "um ambiente de negócios atraente do ponto de vista empresarial", reunindo instrumentos de impulso financeiro e regulatórios que "tornem viável o aproveitamento das novas oportunidades de desenvolvimento e criação de novos negócios" (MMA, 2008, p. 132).

Por outro lado, nas escalas mais detalhadas, os monocultivos avançam pelo campo brasileiro e ganham legitimidade ambiental com os supostos serviços que as florestas plantadas podem contribuir para a "estabilização das mudanças climáticas", por meio do sequestro de carbono da atmosfera e de seus potenciais energéticos. Essa legitimação - baseada a priori na hipótese das mudanças climáticas antropogênicas - compõe parte da "presente estratégia do Estado visando à consolidação do país como grande exportador de commodities, produtos de baixo valor agregado e intensivos em recursos naturais" (MARQUES, 2012, p. 9).

Na outra ponta do processo, as transformações na ocupação e uso do solo em áreas de produção de eucalipto (assim como outras monoculturas) acarretam grandes mudanças para os municípios que abrigam as plantações e unidades fabris de papel e celulose.

Como observa Marques (2012), atualmente no Brasil há um forte avanço da fronteira agrícola em áreas dos estados do Maranhão, Tocantins, Piauí e Bahia - conjunto esse denominado pela sigla MATOPIBA -, ao passo que, por outro lado, ocorre o reordenamento do espaço agrário em estados onde a agricultura moderna capitalista está presente há mais tempo como São Paulo, Paraná, Mato Grosso do Sul e Goiás. É, nesse contexto,

que em resposta à crescente demanda mundial de papel e celulose, ocorre a difusão de monoculturas de eucaliptos e de pinus em extensas áreas no campo, em concorrência com outros usos da terra, e surgem novas formas de produção da natureza relacionadas a novos mercados e estratégias de acumulação e espacialização (MARQUES, 2012, p. 8).

A atual expansão do setor de papel e celulose no Brasil decorre de uma série de fatores, dentre eles os incentivos estatais por meio de 
Produção da Natureza e Impasses Socioecológicos no Extremo Sul Baiano: Considerações Sobre Mudanças Climáticas Globais e a Indústria de Papel e Celulose, pp. 141-171.

financiamentos direcionados a esse setor, mas, também, por meio de incentivos vinculados as políticas ambientais, especialmente sobre mudanças climáticas. Verifica-se que há uma clara predisposição das políticas públicas em valorizar a difusão da agricultura moderna capitalista em detrimento da produção familiar de gêneros alimentícios.

Nesse sentido, a questão climática atual é extremamente preocupante tanto pelos efeitos que as mudanças do clima já estão provocando em todo o planeta, quanto pela maneira com a qual as políticas públicas direcionadas para o tema vêm sendo tratadas.

Muitos dos processos aqui relatados que vem afetando o metabolismo socioecológico do extremo sul baiano - a segurança alimentar, o comprometimento de corpos d'água, o êxodo rural, entre outros impactos -, são, também, objeto de discussão entre as políticas internacionais sobre mudanças climáticas e apontados pelos Relatórios de Avaliação do IPCC como consequências da elevação da temperatura terrestre decorrente das emissões antrópicas de gases efeito estufa.

É inegável que uma parte das emissões de gases efeito estufa é provocada por ações antrópicas e que estas devem ser reduzidas com o intuito de se estabilizar a concentração de gases poluentes na atmosfera. Porém, se atentamos para os mecanismos que se criam para efetuar tais reduções percebemos que fazem parte de operações direcionadas pelos mercados financeiros, convertendo-se em novas ferramentas de acumulação de capital e sendo utilizadas como salvo conduto para a expansão dos monocultivos no Brasil.

Portanto, é fundamental abordar esses processos a partir das dinâmicas reprodutivas do capital que aprofundam os efeitos adversos das mudanças climáticas. Efeitos esses, aliás, que não se restringem aos que já impactam diversas partes do mundo, mas, também, aos efeitos que a dimensão política das mudanças globais do clima pode ocasionar para um desenvolvimento geográfico - ainda mais - desigual no campo brasileiro. 


\section{REFERÊNCIAS BIBLIOGRÁFICAS}

ARDINAT, G.. "Competitividade, símbolo dos paradoxos da globalização". Le Monde diplomatique Brasil. São Paulo, ano 6, ed. 63, 2 out. 2012.

ASSOCIAÇÃO BAIANA DE EMPRESAS DE BASE FLORESTAL (ABAF). Bahia florestal. Oportunidades de negócios sustentáveis. Salvador: Abaf, 2011.

ASSOCIAÇÃO BRASILEIRA DE PRODUTORES DE FLORESTAS PLANTADAS (ABRAF). Anuário Estatístico da Associação Brasileira de Produtores de Florestas Plantadas. Brasília-DF, 2012. Disponível em: <http://www.abraflor.org.br/estatisticas/ABRAF12/ABRAF12BR.pdf>. Acesso em: 9 set. 2012.

ASSOCIAÇÃO BRASILEIRA TÉCNICA DE CELULOSE E PAPEL (ABTCP). A inserção do setor de papel e celulose no contexto da implementação dos esforços globais para a estabilização do clima. São Paulo: ABTCP, 2009.

BANCO NACIONAL DE DESENVOLVIMENTO ECONÔMICO E SOCIAL (BNDES). Impactos da indústria canavieira no Brasil. $\mathrm{Em}$ <http://www.ibase.br/userimages/Livro_BNDES.pdf>. Acesso em: 10 jan. 2013.

BRACELPA. Relatório estatístico anual 2009-2010. Disponível em: <http://www.bracelpa.org.br/bra2/sites/default/files/estatisticas/rel20 09.pdf>. Acesso em: 4 mar. 2012.

. Brazilian pulp and paper industry. 2011b. Disponível em: <http://www.bracelpa.org.br/eng/estatisticas/pdf/booklet/booklet.pdf

> Acesso em: 20 mar. 2012.

BRASIL. MINISTÉRIO DE CIÊNCIA E TECNOLOGIA (MCT). Política Nacional sobre Mudança do Clima - PNMC. Lei No 12.187. Brasil. Ministério de Ciência e Tecnologia 2008 Projeto de lei que institui a Política Nacional sobre Mudança do Clima. Diário Oficial da República Federativa do Brasil Brasília-DF, 2009.

. MINISTÉRIO DO MEIO AMBIENTE (MMA). Plano Nacional sobre Mudança do Clima (PNMC). Brasília-DF: Comitê Interministerial sobre Mudança do Clima, 2008.

BITTENCOURT, M. "MST invade fazendas da Suzano Papel e Celulose". A tarde, Eunápolis, 2012. Disponível em: <http://atarde.uol.com.br/noticias/5825718>. Acesso 4 de abril de 2012.

BORBOREMA, A. "Comissão Ambiental de Mucuri x Suzano Papel e Celulose". Itabatã News. Disponível em: <http://www.itabatanews.com.br/home/leitor.php?cod=1887>. Acesso em: 27 out. 2012.

CASTREE, N. The nature of produced nature: Materiality and knowledge construction in Marxism. Antipode, n. 27, p. 12-48, 1995. 
Produção da Natureza e Impasses Socioecológicos no Extremo

Sul Baiano: Considerações Sobre Mudanças Climáticas Globais e a Indústria de Papel e Celulose, pp. 141-171.

. Marxism, capitalism, and the production of nature. In: CASTREE, N.; y BRAUN, B. (comps). Social nature. Theory, practice, and politics. Oxford: Blackwell, 2001.

CLEAN DEVELOPMENT MECHANISM. Disponível em: <http://cdm.unfccc.int/EB/index.html>. Acesso em: 15 dez. 2008.

CORNETTA, A. A financeirização do clima: uma abordagem geográfica do mercado de carbono e suas escalas de operação. São Paulo: Annablume/Fapesp, 2012.

CORRÊA, F. F.. O licenciamento ambiental da silvicultura de eucalipto no Estado da Bahia. Salvador: Núcleo Mata Atlântica, 2008.

DEMERITT, D.. Being constructive about nature. In: CASTREE, N.; y BRAUN, B. (comps). Social nature. Theory, practice, and politics. Oxford: Blackwell, 2001.

EMBRAPA. "Transformações de plantas". Documentos/Embrapa Cerrado, Brasília, n. 102,2003.

FAIRHEAD, J; LEACH, M.; SCOONES, I.. Green Grabbing: a new appropriation of nature?. Journal of Peasant Studies, 19 abr.. London: Routledge, 2012.

FALEIROS, M. "Mercado de carbono ainda é celeiro de oportunidades e desafios". Revista O Papel, 10 set. 2009, p. 24-27. Reportagem especial. Disponível em: <http://www.revistaopapel.org.br/publicacoes.php?id=284\# anexo718 >. Acesso em: 16 abr. 2012.

FEDERAÇÃO DE ÓRGÃOS PARA ASSISTÊNCIA SOCIAL E EDUCACIONAL (FASE). Carta de Porto Seguro. Disponível em: <http://www.fase.org.br/projetos/clientes/noar/noar/UserFiles/12/File /Rede_alerta/cartas_manifestos/557_carta_porto_seguro.pdf $>$. Acesso em: 25 set. 2012.

FGV EAESP. Disponível em: <http://www.gvces.com.br/index.php?r=site/conteudo\&id=157>.

Acesso em: 12 jul. 2013.

FONTES, S.. Futura Gene aplica R\$40 mi entre Brasil, China e Israel. Valor Econômico, São Paulo, 22 de jul. 2011. Disponível em: <http://www.valoronline.com.br/impresso/empresas/102/460317/futu ragene-aplica-r-40-mi-entre-brasil-china-e-israel>. Acesso em: 22 abr. 2013.

HARVEY, D. O novo imperialismo. São Paulo: Loyola, 2004.

Justice, Nature and the Geography of Difference. New York: Blackwell, 2006.

INTERGOVERNMENTAL PANEL ON CLIMATE CHANGE (IPCC). Mudança do Clima: Mitigação da Mudança do Clima. Sumário para os Formuladores de Políticas: 40. Relatório de Avaliação do IPCC, GT III, 2007. 
KATZ, C.. Whose nature, whose culture? Private productions of space and the "preservation" of nature. In: CASTREE, N.; BRAUN, B. (comps). Remaking Reality: Nature at the Millenium. New York: Routledge, 1998.

LUXEMBURGO, R.. A acumulação do capital. v. 2. São Paulo: Abril, 1984.

MARQUES, M. I. M.. Análise geográfica da expansão recente da indústria de papel e celulose no campo brasileiro, o caso do Grupo Suzano Papel e Celulose. Projeto de pesquisa apresentado ao CNPq (MCTI /CNPq /MEC/CAPES) n. 07/2011, São Paulo, 2012.

MARX, K. O Capital I: Crítica da economia política. São Paulo: Abril Cultural, 1983.

- Manuscritos Econômico-Filosóficos. In: Os pensadores. São Paulo: Abril Cultural, 1978.

MEIRA FILHO; MACEDO, I.. "Etanol e bioeletricidade. A cana-de-açúcar no futuro da matriz energética" In: UNIÃO DA INDÚSTRIA DE CANA-DEAÇÚCAR. Os biocombustíveis no combate ao aquecimento global. São Paulo: UNICA, 2009.

MENDES, J. B.. Estratégias e Mecanismos Financeiros para Florestas Plantadas. Curitiba: FAO/Programa Nacional de Florestas do Brasil, 2005.

ORGANIZAÇÃO PARA A COOPERAÇÃO E O DESENVOLVIMENTO ECONÔMICO (OCDE). Environmental goods and services. An assessement of the environmental, economic and development benefits of further global and trade liberalisation. Paris: OECD/OCDE, 2000.

PIGOU. A. C. La economia del bienestar. Madrid: M. Aguilar, 1946.

PORTAL BRASIL. Disponível em: <http://www.brasil.gov.br/meioambiente/2010/11/metas-domesticas >. Acesso em: 2 set. 2013.

REDE NACIONAL DE BIOMASSA PARA ENERGIA (RENABIO). Disponível em: <http://www.renabio.org.br>. Acesso em : 9 jul. de 2013.

ROCHADELLI, R.. A estrutura de fixação dos átomos de carbono em reflorestamentos. 2011. 86f. Tese (Doutorado em Ciências Florestais) - Universidade Federal do Paraná, Curitiba, 2001.

SANTOS, C.; SILVA, J. C. da. Os impactos do plantio de eucalipto e da produção de celulose em comunidades tradicionais no Extremo Sul baiano. Campinas: Unicamp, 2004.

SECRETARIA DO MEIO AMBIENTE (SEMA); LABORATÓRIO INTERDISCIPLINAR DE MEIO AMBIENTE (LIMA/UFRJ). Avaliação Ambiental Estratégica dos Planos de Expansão da Silvicultura de Eucalipto e Biocombustíveis no Extremo Sul da Bahia - AEE Extremo Sul. Relatório Executivo. Salvador: SEMA, 2011.

SILVEIRA, E. Mais celulose por centímetro quadrado. Revista da FAPESP, ed. 204, fev. 2013. Disponível em: <http://revistapesquisa.fapesp.br/2013/02/11/mais-celulose-porcentimetro-quadrado>. Acesso em: 20 jun. 2013.

SMITH, Neil. Desenvolvimento desigual. São Paulo: Bertrand, 1988. 
Produção da Natureza e Impasses Socioecológicos no Extremo

Sul Baiano: Considerações Sobre Mudanças Climáticas Globais e a Indústria de Papel e Celulose, pp. 141-171.

SUZANO. Relatório de Sustentabilidade. 2010. Disponível em: <www.relatoriosuzano2010.com.br>. Acesso em: 25 mar. 2012.

. Relatório de sustentabilidade 2011. São Paulo: Contadino, 2011.

VIANA, M.. O eucalipto e os efeitos ambientais do seu plantio em escala. 2004. Disponível em <http://bd.camara.gov.br/bd/>. Acesso em: 10 ago. 2010. 